\title{
Mobilizing Water Actors and Bodies of Knowledge. The Multi-Scalar Movement against the Río Grande Dam in Málaga, Spain
}

\author{
Bibiana Duarte Abadía ${ }^{1, *}$, Rutgerd Boelens ${ }^{1,2,3,4}$ and Lucas du Pré ${ }^{2}$ \\ 1 Centre for Latin American Research and Documentation (CEDLA), University of Amsterdam, \\ 1018 WB Amsterdam, The Netherlands; rutgerd.boelens@wur.nl \\ 2 Department of Environmental Sciences, Wageningen University, 6708 PB Wageningen, The Netherlands; \\ lucasdupre23@gmail.com \\ 3 Faculty of Agricultural Sciences, Universidad Central del Ecuador, Ciudadela Universitaria, Quito 170129, \\ Ecuador \\ 4 Department of Social Sciences, Pontificia Universidad Católica del Perú, Av. Universitaria 1801, San Miguel, \\ Lima 15088, Peru \\ * Correspondence: bibiana.duarte@gmail.com or B.A.DuarteAbadia@cedla.nl; Tel.: +31-685-615-869
}

Received: 4 July 2018; Accepted: 3 January 2019; Published: 26 February 2019

\begin{abstract}
Just as in other parts of Spain, the Guadalhorce Valley, Málaga, has a long history of policies based on 'hydraulic utopianism' (regenerationist and Franco-ist), bent on 'reorganizing' political, geographic, and human nature. Residents of the neighboring sub-basin, the Río Grande valley, have seen how these policies, designed to transfer rural water to modern urban centers, have turned the Guadalhorce hydrosocial territory into a 'hydraulic dystopia'. In this article, we examine how Río Grande valley residents mobilized to maintain control over the development and use of their resources, livelihoods, and knowledge systems, when modernist-urbanist policies planned to take their water from a major dam on the Río Grande. Interviewing actors at different scales we examined how this anti-dam movement organized massively in a creative, multi-actor, and multi-scale network. Our results also show that this unified, successful fight against the 'common enemy', the mega-hydraulic construction, has become more complex, as threats crop up not only from the 'city over there' but also from 'internal' hydro-territorial transformations. These sprout from policies to modernize traditional irrigation systems, supposedly to 'save water', but critical voices assume that it is all about passing on the 'surplus' to Málaga city, or using that water to expand agribusiness. We conclude that the challenge lies in critically integrating multiple forms of knowledge, stakeholders, and scales to both defend collective water management and creatively construct anti-hegemonic alternatives.
\end{abstract}

Keywords: hydrosocial territory; knowledge encounters; hydraulic utopia; modernity; commensuration; anti-dam movement; Málaga; Spain

\section{Introduction}

Spain's history of political and geographic re-organization is intimately linked to the 'hydraulic utopia' urged by the Regenerationist movement, and paradoxically, implemented during the Franco period [1-4]. The aim was to technocratically control rivers by establishing interconnected dams, to geographically distribute water more fairly, as hydro-solidarity between the country's rainy and dry zones, to enhance agricultural production, and to integrate rural economies into the industrial and energy sectors. However, in Andalucía, as in other regions, creating hydraulic utopia has significantly contributed to the environmental degradation of rivers, abandoned croplands, the 
urbanization of nature, the bureaucratization of traditional autonomous irrigation systems, the flooding and displacement of towns, and the marginalization of farmer knowledge systems regarding local management of water sources [2,3].

The legacy of these historical actions and the emergence of new, modernistic plans threatening to re-organize water flows, territories, and human population groups now meet with a growing response. Civil society alliances have resurrected folk vernacular knowledge, practices, and forms of social organization, to propose alternative ways to manage and use their rivers' water. One such alliance is the 'Coordinating Body to Defend the Río Grande', belonging to the Guadalhorce basin in Málaga Province. Through this case, we will illustrate how social mobilization has shown the capacity to construct social networks with diverse stakeholders, mobilize much of civil society, and challenge dominant modernistic discourses backing dam building and hydrosocial transformation of the sub-basin, also see References [3,5-7]. This gave rise to the Río Grande movement (hereafter the 'Coordinating Body') seeking to exercise hydro-ecological democracy and impact policy-making, in order to set the Río Grande's water free.

Despite the social movement's success in stopping the hydraulic mega-project on the Río Grande in 2001 and 2006, dominant political and economic powers continue to insist on damming the Río Grande, a project revived lately by tourism growth in the city of Málaga [7]. In this arena, stakeholders with diverging interests wield their different strategies, resources, and discourses to get the upper hand. Repercussions include contrasting, legitimizing or de-legitimizing different knowledge systems or repertoires. This article analyzes the different historical phases through which the different knowledge systems face off, mobilizing discourses and counter-discourses, and hefting their power to influence how the Río Grande hydrosocial territory is configured.

The article is structured as follows: The second section shows the methodology, the third one conceptualizes how encounters among the different life-worlds co-constituted confrontations among diverse knowledge systems [8], which also directly impact the constitution of 'hydrosocial territories' [9]. The fourth part illustrates and analyzes how, in the course of time, a powerful knowledge system has imposed itself over the others in the Guadalhorce basin. We particularly analyze experts' (engineering) knowledge versus grassroots knowledge, their respective alliances and powers that are constituted to debunk locally existing truths and thereby transform realities. We will also examine how, as a response, alternative knowledge systems revalue the sub-watershed's history, ecology, and local socio-economic livelihoods.

In the last part, we explain and conclude how the unified struggle to prevent the Río Grande dam's construction becomes more complex and fragmented by the subtle penetration of powerful interests tied to less visible threats, in particular the policies of modernizing and upgrading technology in traditional irrigation systems, which-like building the dam-equally aim to transfer rural water to urban centers. While some farmers and communities therefore oppose this modernization of their irrigation systems, others see modernization and investment in their irrigation technologies as a guarantee to conserve their water rights and defend them when confronted with the powerful water interests of the city of Malaga.

\section{Methodology}

Applying a political ecology approach to water control, the article discusses the findings from various periods of fieldwork (2015-2017). We conducted 68 semi-structured interviews with different groups of actors in the Río Grande sub-watershed. These were selected through snowball sampling and grouped according to their place of action. The first group involved farmers and their irrigators' organization using the seven community-operated canals (acequias), comprising the Río Grande irrigation system. With this group, including small and middle-class farmers and agribusiness enterprises, we conducted 30 interviews.

The second group refers to the social leaders who formed the 'Coordinating Body to Defend the Río Grande', a local societal movement representing the inhabitants of Coín Municipality, who 
opposed the dam's construction. With this group we conducted 16 interviews. In the third group, we did 10 interviews with scholars who supported the societal movement. Additionally, the last group (12 interviews) consists of officials of the water-supply company (EMASA Municipal Water Company of Málaga) and entities responsible for coordinating water issues, under the Environment Council for the Province of Málaga. Most officials were in favor of the dam construction. The interview questions, structure and settings were adapted according to the group of actors interviewed. Having this diversity of actors, living and acting in different contexts, our research-involving both academic and action-research-includes a balanced sample of the divergent knowledge frames and values that confront in the Río Grande watershed (see also [10]). The interviews were bolstered by field observations and secondary literature review, which includes newspaper articles, official reports, and historical files. The data were triangulated. During the fieldwork the interviews were recorded, transcribed, and coded, and 14 field reports were elaborated to examine the collected data, reflect on research strategies, enrich the upcoming interviews and compare actors' narratives.

\section{Political Ecology of Water: Transforming Hydrosocial Territories and Struggles over Knowledge}

In this paper we use a political ecology focus on 'water', scrutinizing how political forces and power relations shape human knowledge of and interventions in the water world, and how this affects water allocation, management and practices. It examines how dominant modes of water knowledge, water intervention, and water control aim to determine ways of governing nature and society, and simultaneously, define a particular hydrosocial order that organizes access and distribution of water and power among different actors [11]. Our political ecology of water focus therefore concentrates on the (re)constitution of 'hydrosocial territories' [9] as dynamic, disputed spatial, political, and geographic configurations, in which persons, technology, financial resources, legal and economic arrangements, cultural institutions and practices constantly interact to order, distribute, and control water flows and establish ways to govern them. Boelens et al. conceptualize a 'hydrosocial territory' as: "the contested imaginary and socio-environmental materialization of a spatially bound multi-scalar network in which humans, water flows, ecological relations, hydraulic infrastructure, financial means, legal-administrative arrangements and cultural institutions and practices are interactively defined, aligned and mobilized through epistemological belief systems, political hierarchies and naturalizing discourses" [9] (p. 2). Therefore, in addition to aligning diverse social and natural elements, and defining water governance models, competing hydrosocial territories deeply express divergent notions of territoriality, featuring the stories of fights over water appropriation and dominion, contrasting values, meanings, norms, knowledge, identity, and authority.

These contestations to establish 'hydrosocial territory' define processes of inclusion and exclusion, marginalization and development, and distribution of benefits and burdens [12-16]. Significantly, these spatial configurations are informed and aligned by divergent knowledge systems [13,16-18]. Generally, re-organizing hydrosocial territories has responded to the interests of the most economically and politically powerful stakeholders [4,19-22]. However, during this disputed re-configuration, marginalized and anti-hegemonic groups commonly struggle to defend their water, and often mobilize politically and strategically through alliances that combine local, national, and global scales [23-27]. In this way, the hydrosocial territory concept highlights the existence of other, alternative worldviews and vernacular knowledge and how these may co-exist and overlap with, and/or contest, hegemonic forces, structures, and discourses that affect socio-natural reconfiguration. (Related concepts such as 'waterscape' focus particularly on the hegemonic forces that produce water techno-scientific knowledge, discourses and socionature; for a discussion, see Swyngedouw and Boelens [14] (p. 129,130); also see $[9,13,16,18,28])$.

Spain is an important, illuminating case. The country has historically moved toward modernity by implementing water mega-projects and reorganizing nature politically and geographically, attempting to impose a homogenizing, totalizing order [1-4,29]. Universalizing objectivist reason and imposing technical and scientific knowledge have been central factors $[2,14,30]$. This drive to tame and control 
natural order through technical-positivist science and large-scale engineering-a universalizing phenomenon and force that is also present in other parts of the world-has been portrayed as indispensable for cities to develop and grow, and conceptualized as 'urbanizing nature' [31] (p. 276) (for comparison with similar experiences in other regions, see for instance $[12,13,16,22,28,31-41]$ ). For this, a range of modernist 'commensuration' mechanisms are put to work that oversimplify, standardize, and sideline the diversities and complexities intrinsic in life, to build a common metric that will make territories, livelihoods, values, meanings, and knowledge comparisons, which are manageable and governable [42] (see also the Bolivian Misicuni case, in this Special Issue, on defining 'rightful' compensation for dam damages [37]). As a political utopian project, it is rooted, among others, in philosophical thinking that ranges from Francis Bacon [43] to Jeremy Bentham [44,45]—seeking 'the greatest happiness for the majority' by means of calculability, technology, and socio-technical control [46,47].

As we have mentioned above, this utopian national hydraulic project surged in Spain in the late 19th century, when the long-standing transnational empire lost its last colonies. Along with the resulting economic crisis, this materialized the idea that the only way to make up for the country's chaos and backwardness was to colonize itself: By building hydraulic projects, to interconnect the country's bodies of water, mobilizing them to achieve economic development, and build the nation's unity [48-51]. (This process of entwined state-building and nation-building through techno-political water intervention and hydro-territorial reconfiguration is well described in the Menga/Swyngedouw edited volume "Water Technology and the Nation-State" - space, territory, and society are materially, socially, and politically constructed at various, intertwined scales [51] (p. 7)). Building dams demonstrated progress, independence, and modernity, the ability to govern the people and their territories through engineering breakthroughs to control and master the Iberian peninsula's water [52]. Spain's utopian plan of channeling, controlling and damming all water flows to satisfy electrical demand, domestic consumption and cities' industrial production, has been designed with the idea to govern both water and people at once [47]. Political strategies to materialize this 'hydraulic utopia' $[1-3,14,29,47]$ illustrate the mechanisms of standardized modernist domestication of socio-natural geography, making mega-dam construction the epitome of uniformizing control, rationalistic organization, modernist progress, and nationalism [14,30,31,35,53].

In this way, technological developments have accompanied the course of Spain's hydraulic modernity, transforming, appropriating, and instrumentalizing nature and rivers, while orienting patterns of power, generating new social structures, and hydro-territorial orders. Establishing and expanding mega-dams and their massive interconnection would determine new relations among urban, rural and natural life. Spain's history over the last century shows how progressive 'regenerationist' imaginaries regarding political-hydraulic modernization has driven social-ecological transformation, in which imposing reason led the way to irrational acts, violent practices, and mechanisms of exclusion that denied other forms of knowledge and alternative cultural practices [1,3]. What history tells us about modernity is that its policies and politics of invisibility erase diversity and 'inconvenient' social and natural communities [36]; see also [21,35,54-58]. See, for example, the enclosure of the commons in Senegal valley by the completion of Manantali dam in 1987; the powerful bureaucracies building large dams in the Soviet Union; the British colonialist Empire in the early 20th century damming the Ganges and Nile rivers to control exportations of cotton, sugar cane and opium; or the right to expropriate lands that Tennessee Valley Authority created in 1933 for dam building in US, among others [59].

However, contemporary modernity, more than excluding and erasing, also includes controlling anything different, and attempts to involve water-user communities in hydro-territorial projections and the rationalities of governing groups, in order to mold and reinforce the dominant hydro-territorial order [60]. As we will also see in the Río Grande case, this new face of modernity pursues efficient schemes for efficient water use and saving, but in practice it is worsening the unequal distribution of water as well as unsustainable extraction, affecting, and appropriating rural people's natural livelihoods and commons $[29,61-64]$. This way, progress through modernity and hydro-territorial appropriation by 
powerful groups stands on and expands at the expense of local realities: Those domains that still maintain some independence from market forces and universalistic and governmental laws.

In the Guadalhorce region, as elsewhere in Spain, these domains with vernacular values, rooted in diverse cultural practices, have not surrendered. In many places, they have been able to coexist with modernistic transformations, maintaining and fostering values and knowledge that often remain concealed, but are intrinsic within their diverse cultural reproduction strategies and the permanence of othernesses - of that which is distinctly different normatively, ontologically, and epistemologically [65]. This vernacular knowledge emerges through day-to-day practices, as they evolve over time, wisdom-'farmers' knowledge' - is constantly recreated through experience. It is based on rural peoples' capacities to coordinate and adapt to a broad scenario of political and agro-economic uncertainties, generating techno-ecological opportunities that enable them to get the hoped-for results to make their living [66]. This is creative and dynamic, built constantly by selectively incorporating new ideas and prior experiences, based on cultural beliefs and historical and modern sentiments [67].

Foucault [68] conceptualizes such vernacular knowledge, often concealed, as 'subjugated knowledges', referring to them as the bodies of knowledge that have been disqualified for not having been elaborated within scientifically and formally accepted conceptual frameworks. Such knowledge is ignored, deemed irrelevant, and therefore remains underground; ranked as hierarchically inferior by those who hold the power to validate and judge the way they want the majorities to see and understand reality. Therefore, a knowledge hierarchy is implicit in society's interlinking with aspects of power, authority, and legitimacy [8]. Bodies of knowledge do not have absolute validity or truth. Foucault would argue that knowledge, truth, and power are co-defined in a triangular relationship (1980) - it is the nexus of knowledge and power that creates, legitimizes, and lends 'truth' to a certain order of knowledge. It has direct implications to uphold and impose a certain hydraulic policy and the consequent political and geographic reorganization of nature. Here, Long [8] adds that relations between power and knowledge emerge from social interactions, where knowledge involves clashes between stakeholders who want to control and dominate others in their plans to create society and territory. On the battlefield among bodies of knowledge, they try to get their particular frameworks of meanings accepted, to position their ways of viewing life. The hierarchy of knowledge then results from interactions, dialogues and contestations over values and meanings; the legitimacy or invisibility of knowledge hinges on power relationships, establishing forms of authority, normative frameworks, discursive guidelines, and orientation in allocating, controlling and distributing resources.

In this battle of epistemological domains, as we show in the following sections, local groups and their culture and place-born knowledge respond actively to the imposition of knowledge to alter water distribution and governance patterns; they contest the reorganization of their hydrosocial territory. Consequently, political and economic power relations directly impact how and what forms of knowledge will prevail in a given territory. As stakeholders, their ideas, knowledge, and values engage and confront each other, they perpetuate the possibilities of de-constructing dominant discourses and consequently transform their realities. According to Bebbington et al. [23], success in questioning dominant knowledge systems and discourses lies in forming an alliance of multiple stakeholders at multiple scales-local, regional, national, and international. Multi-scale and multi-stakeholder movements, hence, are more effective to actively respond to the imposition of knowledge that alters water distribution and governance patterns. This shapes the political arenas where values, rules, rights, techniques, practices, and knowledge are decided, determining which hydrosocial order will be dominant.

The end of this article will analyze how most rural and grassroots contestations focus not on rejecting modernity, but on reformulating and including it as part of their own projects and proposals, to uphold their livelihoods and defend their water rights and territory (see $[8,11,67,69])$. Thus, modernity is and becomes 'multiple', incorporating the different interfaces and reflecting the conflicts and frictions among epistemological systems and discourses—see the elaborate analysis in the introduction paper 
to this Special Issue, [36]. This also appears directly in technological water development-subject to being contested, appropriated, modified, and altered by the claims and interests of the directly affected population groups [70-72].

\section{The Utopia of Hydraulic Modernity in the Guadalhorce Watershed: A Dystopian Mirror for Residents of the Río Grande Micro-Watershed}

Understanding the knowledge struggle involved in building the Río Grande dam requires illustrating and historically analyzing the political and economic factors impacting the hydro-territorial transformation of the wider Guadalhorce basin, which the Río Grande flows into (see Figure 1). We will analyze how building mega dams and imposing modernistic technical and scientific thinking have driven transformation of the Guadalhorce Valley.

As was mentioned, the thinking of the intellectual-political 'Regeneracionismo' movement and its leader, Joaquín Costa (1875-1911), are fundamental to start with. Costa laid the foundation for Spain's water policy in the late 19th century. His utopian desire centered on designing an idealized society by engineering its water, to transform both humans and nature. As explained above, at that time, Spain was in an economic and political post-colonial crisis, casting about for a water utopia to emerge: Regenerationist intellectuals proclaimed the need to start colonizing internally to regenerate the country. Among Costa's proposals, this self-colonization was geared toward recovering the Arabic hydraulic heritage, empowering rural people, eliminating bourgeoisie, and building a new national identity by technically and politically modernizing water [1,14,29,47,73].

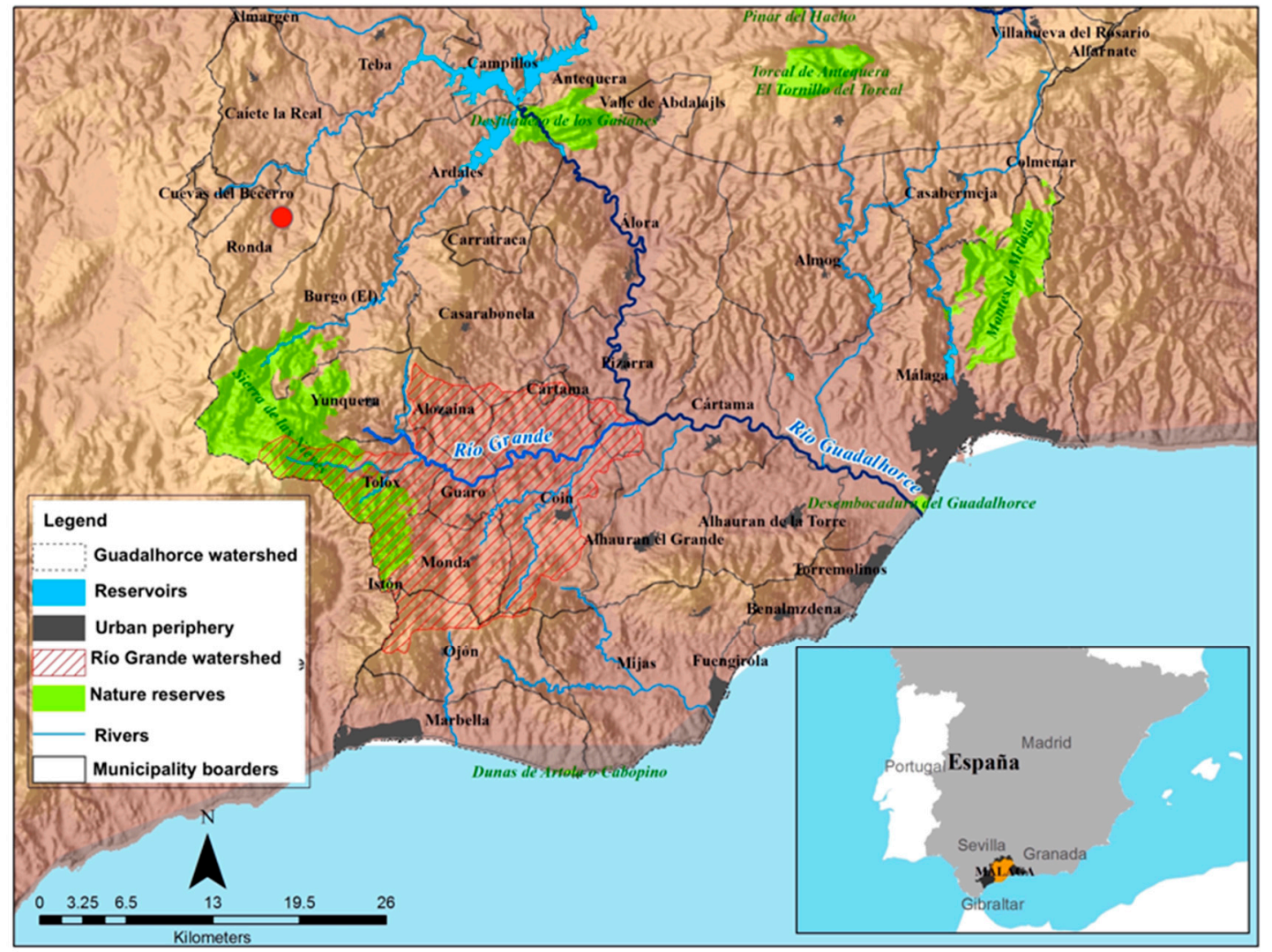

Figure 1. Guadalhorce and Río Grande Basin Location. Source: Andalucía cartographical base, 2015. Prepared by: Pacheco, 2017 [74].

As Achterhuis [46] explains, political and historical utopias always come to mind, and once 'realized', become dystopias. Spain's hydraulic utopia, too, when as all utopias do, it defined the need 
for a total break with the core of the old society, to build a new one. This break has justified violent interventions in and against nature and people cf. [29,47,61].

Following regenerationist ideas, in Spain, the construction of hydraulic projects was driven by modernizing that impoverished society, regenerating culture, land and the whole political-economic system. Constituting irrigation policy, by expanding dams and irrigation systems nationwide, would resolve the country's water scarcity: Its water inequities would be corrected in terms of geographical distribution, and this would also reinforce electrical generation, especially when cities began growing and agro-industrial development took off. Setting up Spain's hydraulic modernity would entail reinforcing the state's role and centralizing political power in the state, as the representative of the whole nation's general interest. For this purpose, water was nationalized. To manage effectively, Costa proposed to create 'the new man' through engineering sciences, so ideological and political alliances between regenerationists and engineers led new 20th century hydro-territorial transformations. The purpose was both to restore the country's geography and to build a new order [1,2,29].

Even when regenerationist projects failed because of the inherent political and economic conflicts between 'old' and 'new', the Franquista mission made sure to implement Costa's hydraulic dream [4]. Socio-spatial power relationships were interwoven between the military, the church, the national industrial bourgeoisie, large landowners, and the state to-among other goals-transform watersheds, which were seen as the integrating backbones of water development and territorial management. Thus, new hydrographic confederations, established in the early 20th century, would connect and integrate plans for the engineering corps' water projects. This would mean fully tapping and controlling rivers' water throughout their course; a totalizing system in which confederations were conceived as a river basin governance organizations uniting all people as a single family-laying the foundations to integrate and colonize the nation's territory after Spain's civil war. The engineers began materializing the regenerationists' water policy thinking, so each dam they built became a symbol of modernity, a concrete step forward, and above all, a homage rebuilding the weakened national identity. Engineers pursued a technical, social, and patriotic mission [29]. A key rhetorical idea was to enhance and unify the vernacular wisdom of farmers, to improve their living conditions through constant, controlled deliveries of water [2]. In reality, though, engineers' knowledge and scientific progress were dominant [30] (p. 7) and it imposed technical-scientific thinking upon rural peoples' local knowledge.

To promote hydraulic policy and thinking in Guadalhorce Valley, engineer Rafael Benjumea, a believer in Joaquín Costa's hydraulic policy, attempted to fix the problems of Málaga society using water mega-projects. One of the first projects was the 'Conde del Guadalhorce' Dam on one of this river's main tributaries. Building this dam was the first step to develop the 'Coordinated Guadalhorce Plan': It centered on capturing, storing, and regulating all the basin's water sources to foster integrated development of agriculture, the electric power industry, drinking water for Málaga city, and flood control. This plan was implemented once dictator Franco came into power (1939-1975). To close up the basin, upgrade the water regime technology, and keep a single drop from reaching the sea [14], two other major dams were built in the basin, on the Guadalhorce and Guadalteba Rivers, from 1966 to 1973 . With $328 \mathrm{hm}^{3}$ capacity, along with the $86 \mathrm{hm}^{3}$ already in the 'Conde del Guadalhorce' Dam, this would provide enough water to irrigate an area of 20.000 ha. However, the priority was to supply water to Málaga, followed by generating electrical energy [2,3] (for an overview of the Guadalhorce dams and hydraulic infrastructure along the river, see Figure 2).

Building these dams entailed dramatically expropriating the affected farms and land. This was enabled by the Forcible Expropriation Law. Franco's state displaced people 'for a price it judged fair'. This Law included forming 'pueblos de colonización' ('colonization towns') and a program of agricultural indoctrination and Franquista discipline. One was the town of Peñarrubia, located at the headwaters of the Guadalhorce River. It was flooded and its inhabitants were displaced to these new towns. Uprooting and de-localizing people was a Franquista strategy to neutralize territories and make them manageable. By pulling up roots, exterminating culture, it was possible to mold a new society [3]. 


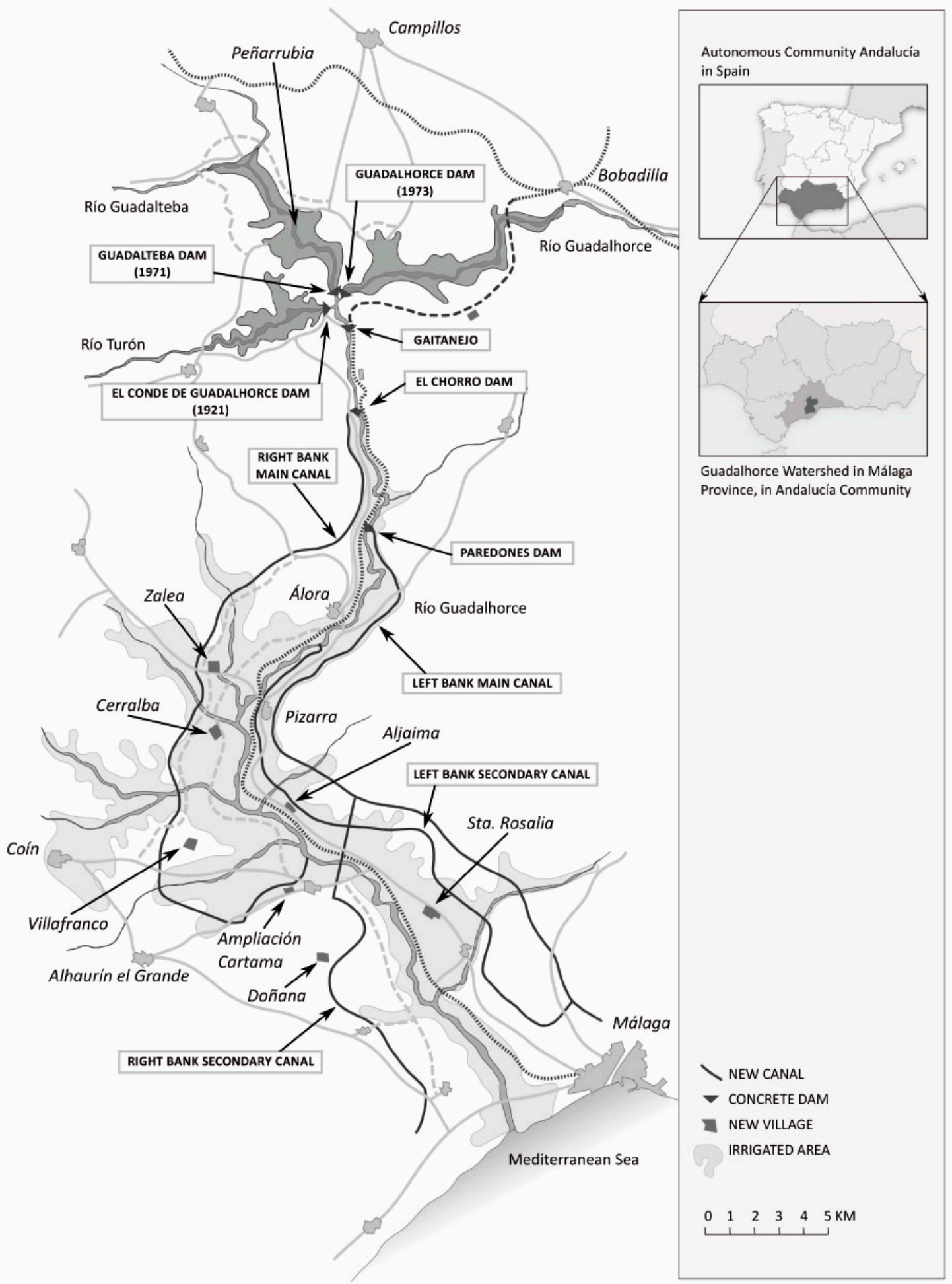

Figure 2. Guadalhorce dams and hydraulic infrastructure along the river. Source: Boelens and Post Uiterweer [2].

These 'colonization towns', located in zones without irrigation, became the buffer zones for migration by rural people whose lands were seized for water projects in Guadalhorce Valley. This hid away the memories, which stayed alive in hiding, of taking away people's towns and zones to flood them. Stories by people from Peñarrubia, for example, stress how rootlessness is an indelible feeling, closely linked with a refusal to erase the past. For this reason, they continue holding a reunion every 
year to commemorate the love they felt for their town [3]. The story of Guadalhorce Valley shows how building the Utopia became a violent, horrible dystopia.

At the same time, the history of the Guadalhorce Valley was the historical mirror, enabling neighbors to continue fighting against the zone's water Utopia, which continued to replicate, now building the Cerro Blanco dam in their sub-watershed, the Río Grande. This work planned to dam the only river still flowing freely to the Guadalhorce, in the mid-basin. The purpose of this dam was to provide water for the tourism industry, concentrated in the city of Málaga. The following sections describe the project's different phases and the diverse societal contestations emerging to prevent its construction.

\section{The Río Grande's Conquest}

\subsection{Planning the Cerro Blanco Dam-Phase 1 (2001)}

When the dictatorship ended and Spain entered the age of democratization, the Politica Hidráulica technocratic model continued to reign over water governance. Since the mid-1980s, it was planned to dam the Río Grande with the Cerro Blanco Dam, already part of the Hydrological Plan for the Southern Basin (PHCS) from 1995. The dam was designed to supply water to Western Málaga city [5,75]. It was also justified to regulate Río Grande's considerable high flows during winter.

The dam on the Río Grande would be constructed in the municipalities of Guaro and Coín (see Figure 3), its reservoir capacity of $32 \mathrm{hm}^{3}$ would flooding 240 ha of land, foreseeing a regulation capacity of $25 \mathrm{hm}^{3}$ /year [76]. In 2001, ACUASUR (Sociedad Estatal Aguas de las Cuencas del Sur), a company created by the government, announced 'The conquest of the Río Grande'. This project was also stipulated in the National Hydrological Plan (2001-2004).

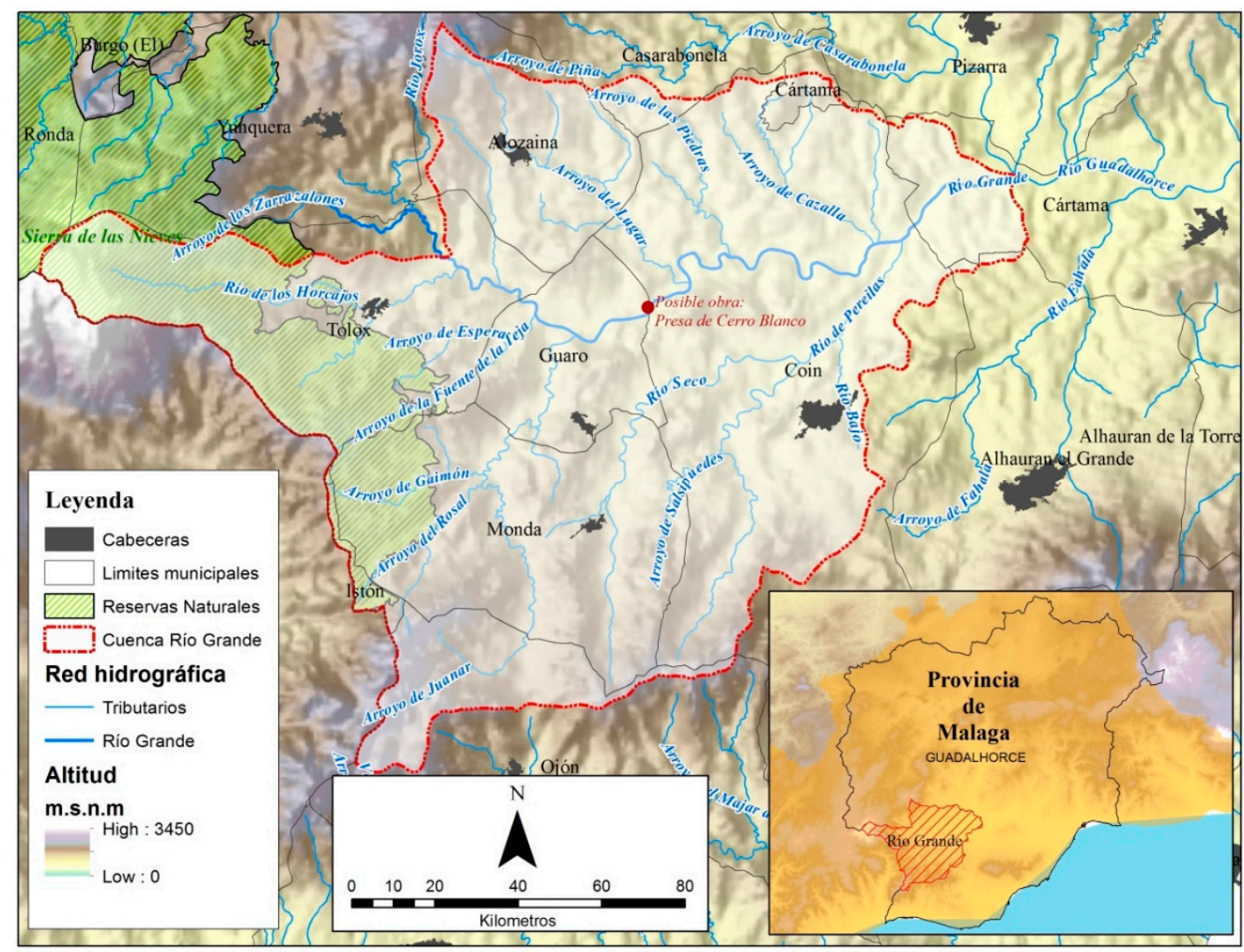

Figure 3. Río Grande basin and Dam location. Source: Andalucía cartographical base, 2015. Prepared by: Pacheco, 2017 [45]. 
This drove the creation of the 'Cerro Blanco Anti-dam Platform', led by farmers from Guaro, in 2001, supported by environmentalists and activists from Coín, grouped in the 'Jara Association'. The members of local offshoots of 'Ecologists in Action' (a federation of over 300 ecologist groups throughout Spain, unified in 1998) also took part, plus the academic sector, who were active members of the national 'Nueva Cultura del Agua' (NCA) movement. (The New Water Culture is a societal movement that emerged in opposition to the inter-basin transfer of the Ebro River and then proposed alternative thinking to change Spain's water management paradigms—appearing in the mid-1990s). Mobilizing the 'Cerro Blanco Anti-dam Platform' was ideologically accompanied and interconnected with the diverse demonstrations opposed to building major hydraulic works contemplated in the National Hydrological Plans of 1992 and 2001. On the national level, the platform joined with the demonstrations against water transfers from the Ebro River valley to the Mediterranean-Platform to Defend the Ebro-and with the Coordinating Body for People Affected by Large Dams and Inter-Watershed Transfers (COAGRET) [56,75,77]. “We also support demonstrations in Catalonia or other parts of the country ... People in Catalonia were surprised greatly to see us take part, because they thought that, since Andalucía would receive more water with the National Hydrological Plan, we should agree with it" (interview, local leader in Río Grande, April 2017).

These movements refused to continue bearing the consequences of deterioration in their aquatic ecosystems and social displacements derived from Franquismo-style national hydraulic policy. Their contestations aimed to protect the few 'living rivers' remaining in Spain that were threatened by the construction of 120 new dams and inter-basin transfer projects. The Cerro Blanco anti-dam platform successfully mobilized to defend the natural environment, with all its biodiversity, orchards and the Arabic-rooted traditional irrigation culture that remains alive in the Río Grande Valley. Guaro farmers' rootedness in their fields and traditional acequias, especially by the elder population, has been passed down to younger generations, and is perceived in local official entities, which supported their protests and were able to present their positions in regional political agencies and curb this dam's construction in 2001 [6,7] (interviews, Río Grande inhabitants, September 2016-September, 2017).

In this phase, we can see how vernacular values and knowledge from the valley's smallholder farmers emerge and revive, contesting hydro-techno-scientific paradigms that were imposed by modernistic hydraulic designs and utilitarian dogmas seeking 'the greatest benefit for the majority'. The Cerro Blanco anti-dam movement expresses that alternative notions of territoriality are still alive, and are very vivid and vital. They powerfully sustain mobilization against a very visible threat, and yield the support of other anti-dam national movements that fight for alternative a world and water-views.

\subsection{Direct Conduction of the Río Grande's Water, Building a Diversion Weir rather than a Regular, Higher} Dam: Phase 2 (2006)

Although dam construction was halted in 2001, in June 2006, a different, but similar, project was approved by the Ministry of Environment. This time, rather than announcing construction of a large dam, they referred to a diversion weir ('azud'), a smaller dam to reroute water by fixing a permanent water level (it would be $7 \mathrm{~m}$ high, to hold $8.4 \mathrm{hm}^{3}$ of water). This way, rather than flooding 171 hectares, water would be directly transferred to Málaga (see Figure 4). A 38-km conduction canal would be built, with a pipe of $1.60 \mathrm{~m}$ in diameter, with the capacity to transport $20 \mathrm{hm}^{3}$ /year, at a flow rate of $4 \mathrm{~m}^{3} / \mathrm{s}$, from the river's high-water flow during winter. Members of the NCA felt the project meant conducting the whole river, because the derivation pipe's diameter could reach full operating capacity of $126 \mathrm{hm}^{3}$ /year, more than the river's total flow, calculated to an average of $80 \mathrm{hm}^{3} /$ year [76].

In fact, the former director of the Andalusian Water Agency (AAA, Agencia Andaluza del Agua) stated in 2010 [5], to reassure the Southern Basin engineers and technicians, that building the diversion dam was only a first step toward later building of the full dam. Likewise, the project officer in EMASA reiterated this: "I drafted the project ... what I did was not the dam, just the conduction, with the 
diversion dam to carry the water through a pipeline, leaving one area dry, and then be able to make the dam" (interview, project manager EMASA, March 2017).

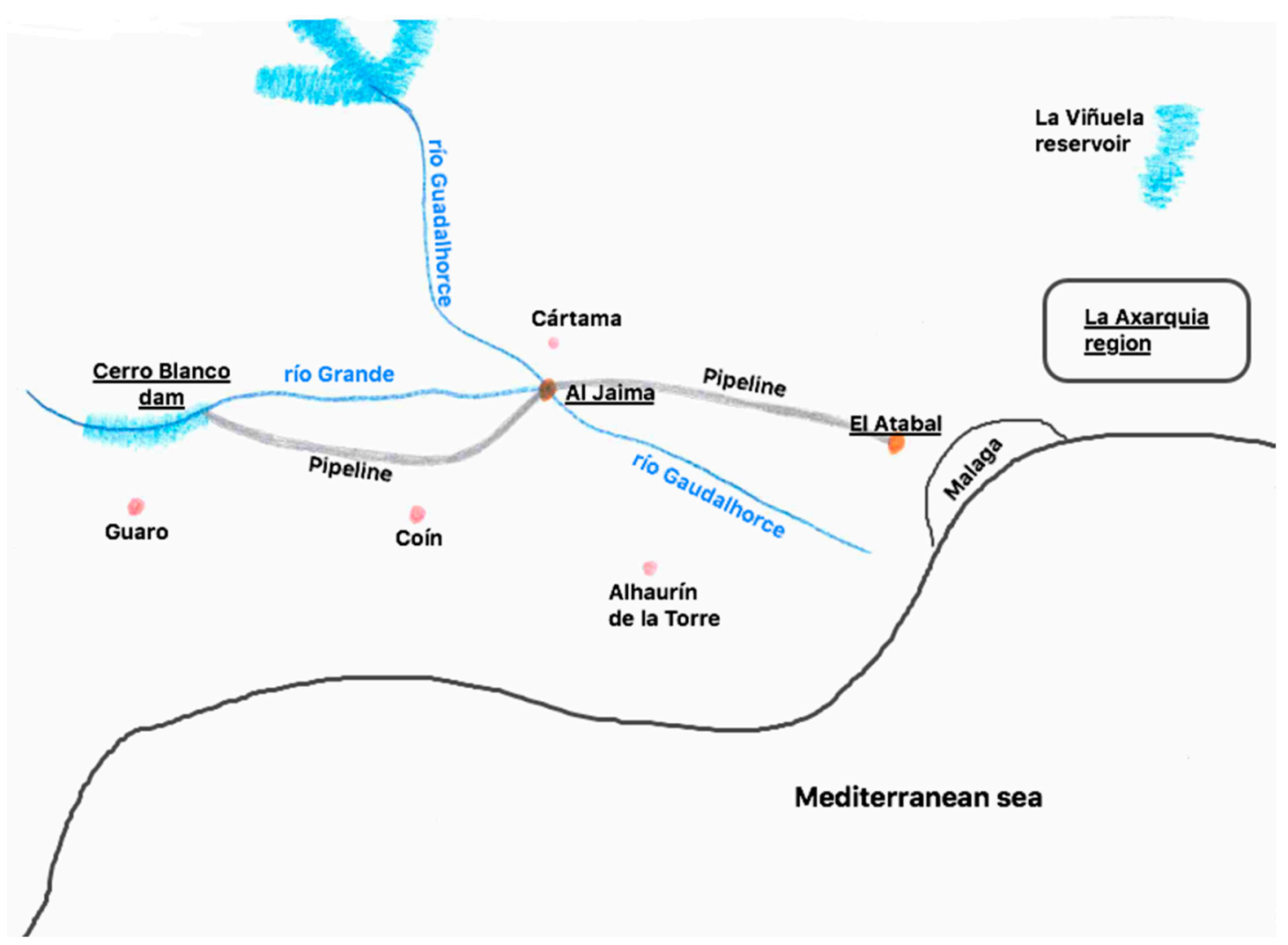

Figure 4. Hydraulic construction to transfer Río Grande water to Málaga. By Lucas du Pré [7].

That same year when the project was approved, 2006, people owning land in Río Grande valley started getting expropriation notices. About 25,000 persons would be affected by the project's implementation, and more than 2500 ha of irrigated croplands would be lost. Coín and Guaro were all living in fear and uncertainty, so they first turned to the local ecologist groups, 'The Jara Cultural Association'. They joined forces also with the Cerro Blanco Anti-dam Platform, and they all formed, in September 2006, the 'Coordinating Body to Defend the Río Grande'. They were also joined by the towns of Pizarra, Cártama, and Alora. "... We united the people to save it, with the analogy, on our movement's logo, of a heart and the river flowing" (interview, Jara Association president in Río Grande, 22 June 2015).

The first strategy by the Coordinating Body was to connect with other local collectives, activists, and academic entities belonging to the NCA. While forming this coalition, the Coordinating Body began an information campaign for residents of Río Grande valley and neighboring citizens. They analyzed the project documentation with intellectual support from the NCA, to then disclose and diffuse it, promoting alternatives. This was their second strategy to reinforce their control over their water and defend their rights to the river: to master their overall knowledge about the project, associating it with urban-rural relations regarding water supply and demand. Accordingly, they organized the data, conducting studies and drafting legal arguments to show that the dam was not viable but there were alternatives to supply Málaga with water (such as watering gardens in summer with treated water and setting up water purification plants to reuse water). "We gave them data on the dam's environmental risks, biophysical data that would make it impossible to build. The protest had everyone well-informed. We moved around, receiving help from scholars and from people in Madrid. It was a very successful movement. The people of Málaga were not the ones asking for that water. It was other interests. 
The politicians started to run out of argument" (interview, Jara Association president in Río Grande, 22 June 2015).

The Coordinating Body's third strategy consisted of maintaining political independence during their mobilization. They did not receive support from any political party, or allow parties to speak for them during the mobilization, which earned them citizens' rapport and credibility. During their mobilization, the Coordinating Body realized that the dam building was being pushed by political interests seeking European Union grant money to build projects. "The large building companies wanted to get grants, because it is not profitable to build a dam. Not even the state makes it profitable, much less the farmers" (interview, local leader in Río Grande, 22 June 2015). The Coordinating Body's independent position and increasing mobilization in 2006 and 2007 got politicians to shift their position, especially since this coincided with the municipal elections in 2007. Candidates had to commit publicly to reject the project to avoid losing votes.

The Coordinating Body's fourth strategy, with financial backing from the NCA, was to conduct a study to value the ecological status of the Río Grande's water, to demonstrate its great biodiversity, and the purity of this sub-watershed's water. The Coordinating Body was working to get this zone declared as a European Union recognized 'Lugar de Importancia Comunitaria' (LIC) to legally forestall any new attempts to build the dam (for more details about LIC see [78]). Even so, in 2009 the Ministry of Environment asked them to pay for an independent study, endorsed by a university to lend it more weight. The Coordinating Body turned to the University of Málaga, but could not afford the price it quoted, so the Jara Association was forced to abandon the legal approach to protecting the Río Grande. "Just now, one of the few things they are afraid of is LICs, because they know Europe values them. So LICs are a good safeguard to prevent the dam" (interview, scholar Málaga Universiy, 24 April 2017).

Due to all the pressure mobilized, in May 2007 the construction of the diversion weir on the Río Grande was discarded, and in December an alternative project was announced to replace it. This $21-\mathrm{km}$ conduction would connect the Aljaima diversion dam (on the Guadalhorce River, just below where the Río Grande joins it) to the desalinization plant in Málaga city (this project was completed in August 2012). This alternative had been proposed from the outset by the Coordinating Body, and studied by the Andalusian Water Agency director, Joan Coraminas, a founder of the NCA. The Jara Foundation put it this way: "We offered alternatives, for Málaga to take its water from the downstream part of the river and not the upstream part; there had already been a diversion dam there for a long time ... its biodiversity." He explained- "That project would cause no impact on the river's course, while achieving the same aims as the large dam" (interview, former Director AAA. 23 March 2017).

In this second phase, expert engineers in alliance with the government continued insisting on transferring water from Río Grande to Málaga. As a response, the social movement showed the capacity to create a diverse social network formed by farmers, scholars, state employees, local inhabitants, youngsters, civil society organizations and platforms, and national/regional/local activists to contest the new project. This multi-stakeholder movement was able to connect different knowledge systems successfully disputing the socio-ecological feasibility of constructing a water offtake dam upstream in the Río Grande. They offered an alternative solution.

In the following section, however, we will describe the new challenges that the social movement has to face when new actors appeared, with new techno-modernist and 'green', 'inclusive' discourses that, however, keep seeking to transfer the rural waters.

\subsection{The Paradoxes of Defending the Rio Grande: Modernizing the Traditional Irrigation System and Silently Transferring Water (2009-2017)}

The slogan 'defending the Rio Grande as a living river' generated a unified, strong mobilization to prevent construction of canals and diversion dams to transfer rural water from Coín to Málaga city. Paradoxically, this idealist slogan became the discourse that other ecologist groups, living in other zones, would use to demand changes in the traditional practices of irrigators' communities using the river, also see Reference [7]. 
During the summers of 2009-2010, the Río Grande community of irrigators was sued by the Environmental Prosecutor's Office. The suit was brought by the 'Association of Fish Conservation and Aquatic Systems of the South' (ACPES). They argued that building traditional diversion dams that irrigators used to catch the river's water and get it into their ditches was killing fish, harming the balance of natural systems. ACPES felt the summer drought on the Río Grande was caused by multiple river water extractions, many 'illegal' (that is, informal), and therefore the most visible ones had to be brought under control. Consequently, the river guard began ongoing surveillance during the summer in 2009-2010 to prevent irrigators' communities from deploying the practices they had always used. Irrigators felt such procedures were a legal instrument being used against them to call the attention of the Andalusian Council and de-legitimize their customary water rights.

In addition to this pressure, also motivated by the EU Water Framework Directive that aims for water saving, protection, and river restoration, recent Spanish water policy considers water as a scarce resource [7] and has introduced market laws in which water management must obey economic rules of efficient use [41,57]. Among others, this entailed regulating irrigators' communities, persuading them to officially register and renew their concessions, according to actual water availability and subject to the new demands. Not all Río Grande irrigators' organizations abided by this legislative procedure and consequently some lost their legal recognition and water rights. Simultaneously, besides aiming to minimize their existing volumetric water rights, the Department of Water Authorizations and Concessions of the Andalusian Council has restricted the granting of new concessions for irrigation in the Río Grande zone, because the water table has been judged to be lowering and in poor condition. Moreover, the Department of Hydrological Planning and the Andalusian Irrigation Plan (1986) introduced the need to adopt 'water saving' measures as strategy to mitigate the impacts of climate change and support sustainable rural development (see: "Plan Nacional de Regadíos, horizonte 2008" (Real Decreto 329/2002) and "Plan de Choque de Regadíos" (Decreto287/2006), [79]).

The main regulatory strategy to prevent water scarcity and optimize water redistribution to the other societal sectors is to promote 'irrigation modernization', especially replacing 'riego a manta' (blanket watering, traditional surface irrigation) by drip techniques [80]. "They will have to stop surface irrigation, because it squanders water! The Administration will help them with pressurized pipe systems or other modernizing, by granting subsidies" (interview, former Environment Delegate, Andalusian Council, 28 April 2017). Modernization is justified as a way to overcome 'the shortage of water in the river. In 2010-2011, the first dialogues began with and within the community of irrigators, to start modernizing their irrigation. This technology changeover began with Andalusian Council support, offering grant funding. However, a key issue was that, to receive grants, the irrigators' community would have to change its concession rights, reducing the volume habitually allocated. In fact, they dropped from $7500 \mathrm{~m}^{3} /$ ha/year to $5500 \mathrm{~m}^{3} /$ ha/year. In the end, however, bureaucratic procedures made did not get economic benefits, but their water rights were cut, anyway. Nevertheless, a group of Río Grande micro-entrepreneurs and agribusiness producers have subsequently taken the lead in modernization. They have a personal interest in technological modernization, because year-round water access will benefit their agri-business companies. The irrigation system with traditional 'acequia' canals works only in summer, but the modernized system would work all year round. With an expert in modern irrigation engineering, they organized and persuaded other members to cover the costs of modernization.

\section{Current Hydrosocial Territorial Transformations}

\subsection{Contested Knowledges and Internal Frictions}

Contemporary modernization has created new legal and epistemological authorities who have now begun to wield technical, legal and financial control, setting up new water rights arrangements for irrigators. One involves the rights to access river water. The community of irrigators has stopped building their own little diversion dams and now get their water by digging down to the water table, 
near the river's course. They pump water from these wells directly to the piping laid over the former ditches. Measures devices allocate each farmer a flow rate, according to the land they own. "Now we are forbidden to touch the river, and we have to dig a well to get water. The ecologists, environmental authorities, don't want us to touch the river because of its biodiversity ... so they have changed our water concession" (interview, smallholder from Valenciana ditch, 6 April 2017).

These changes in rights to access the river also transform the hydro-ecological self-regulation used to operate traditional irrigation systems, and make new arrangements to distribute and allocate water to each irrigator. Modernization, according to Río Grande residents' local knowledge, by changing groundwater flows, will take away water from other local sources: Wells, aljibe cisterns, and aquifers. The reason is that water has always been conducted through ditches, to flood their fields, which simultaneously recharges groundwater: Feeding aquifers, wells, or aljibe cisterns for other fields downstream, and finally returning percolated and excess water to the river. Understanding this, many residents and farmers do not view surface irrigation as a 'squandering' of water. They feel that the government, experts, and agribusiness farms are actually promoting a strategic discourse to marginalize traditional systems and thereby justify drip irrigation. "Whenever we flood our fields, a few hours later all our wells are totally full. These wells are more than 20 meters deep. People call me to say their wells are dry, and after a few hours of irrigation, they have filled right up" (interview, water distributor of Guaro ditch, 10 March 2017).

Many irrigators also hesitate to join in the modernization, because this undermines their local water self-governance. Once ditches are replaced by pipes, water distribution is no longer a matter of shared work or collective decision-making. It becomes an individualized affair, controlled by a few who use technological artifacts to take over water distribution. Moreover, many feel that modernization is not a profitable alternative, because of low produce prices, versus the high start-up costs and energy costs to extract water. Most farms are small, cultivated for self-supply. This means that most cannot afford to modernize and will lose their water rights in the future. Further, some farmers fear that modernization, in the medium term, could facilitate transfer of presumably 'shared' control of the new water infrastructure with the Andalusian Council, to elites and formal rulers exclusively. Agribusiness farmers, who are leading modernization, would get control over water management. "I don't like this modernization, because we lose our ditches. They are making some installations ... It is a political plan. The Council will never be stopped. They have decided to implement the project, and then take it over" (interview, inhabitant Río Grande, 24 March 2017).

However, many irrigators who did decide to join in the modernization (approximately $30 \%$ of the total community) said it was their only alternative to avoid forfeiting their water rights to the river, to keep farming, keep their cropland and leave it to their children in better conditions. Entering the modernization would guarantee them their right to community water, because it would show that they were adapting to environmental standards oriented toward economizing water and protecting the ecosystem, giving them a legal, administrative guarantee and therefore water security to confront the new intention to transfer Río Grande water to other places such as Málaga. Their traditional irrigation practices, building a small dam to catch water from the river and do 'surface irrigation', would no longer be accused by environmental authorities, ecologists, or fishers' associations. "I have a private well ... but I want to be in the community to be able to pressure for that water right. Because if the well dries up ... Who will listen to my problems? I want a common project, where we can exert more pressure when we need to complain. I want to conserve our common rights, for a sector that is respecting diversity" (interview, farmer Río Grande, 4 March 2017). "There are still many of us who want to grow some food.... Modernizing was the only way to continue irrigating" (interview, farmer Río Grande, 3 March 2017).

According to critical voices, modernization aims to free up water flows to transfer it to places that concentrate demand and economic power. This is another way to transfer local water to urban and business centers. By saving water and preventing the supposed 'loss of water' in the irrigation system, they will assure that water is available for the tourist industry and urban demand concentrated on the 
Mediterranean coast. In the words of a Universitat Politècnica de València scholar: "In Andalucía, they keep promoting that type of infrastructure to make maximum use of available resources. The intention to improve is not for the environment, or to recover the river flow or continue applying the water framework directive ... but in response to the old model's interests, modernistic capitalism, and put as much land as possible into production" (interview, 24 March 2017).

In fact, irrigation modernization continues to uphold the same supply management model that has developed while building large water projects. It has been turned into a subtle social strategy, reconciling the notion of 'maximum water saving' under two social positions: Protecting ecological flows, and allocating water to places where population is concentrated. However, their effects are contradictory: extraction of ground water is multiplying, escaping from collective and even official control. Further, we see in the case of the Río Grande's communities how irrigation modernization divides these communities from within, undermining local water self-governance and resulting in a new hierarchy of knowledge and values where expert know-how and standards dominate, along with their allied political and economic power groups. The next section clarifies how these consequences influence the fight against the 'common enemy', the hydraulic mega-project on the Río Grande-a fight that still carries on.

\subsection{New Announcement of the Dam (2016-2017)}

In late 2016, the heavy rains flooded Málaga, the city was on red alert. Consequently, officials on the Andalusian Council announced, in different newspapers, the need to revisit construction of the Cerro Blanco dam on the Río Grande.

Beyond controlling and regulating water flows to prevent flooding, there are multiple other needs, interests, and pressures. The mayors of neighboring municipalities have urbanization projects on hold because they cannot guarantee their water supply. Further, the agri-businesses in Axarquia, a province of Málaga to the East, intensively growing tropical crops, express the urgent need for this dam, because they have over-pumped their own aquifers; if the dam is not built, they warn of serious repercussions in the province's economy. They want to freely use water from another dam near them, the Viñuela dam, which at this moment, against their interests, is mostly to supply Málaga.

EMASA, the water supply company in Málaga, is another sector pressuring the Andalusian Council to implement the project. They want to access the clean, pure water from the Río Grande mid-range. This would also 'correct' the technological deficiencies (e.g., saline water) of Franquismo dams on the Guadalhorce River, which at this moment are the key water suppliers for the city. Finally, it will represent a savings in energy costs for the company; the current water diverted to Málaga must be pumped, whereas water from the Río Grande would run down by gravity.

These alarms reactivated the mobilization of leading members of the 'Coordinating Body to Defend the Río Grande'. Their messages rejecting this type of projects were broadcast on local television and direct appointments with the mayor of Coín. Their demands this time focused mainly on defending the Río Grande's territory and croplands-these farms provided livelihoods for a number of families who lost their jobs during the country's economic crisis from 2008-2014.

The Coordinating Body demands, before thinking about damming the Río Grande, that they invest in technologies to clean and recycle waste-water for each urban area in the Río Grande sub-watershed - money already granted by the EU but not yet implemented due to political negligence. Further, the social movement declared that the late 2016 flooding was not for lack of a dam, but because of irregularities in urban planning; the places flooded were wetlands and old river courses, which used to belong to the river. In addition, the Coordinating Body argues that the dam argument is false, and anyway, surplus water, flooding urban zones near Málaga, was not from the Río Grande sub-watershed, but from the Guadalhorce River itself, which is exactly the river that was totally dammed by the hydraulic dystopia and its enlightened modernistic experts' know-how.

Farmers who have joined in irrigation modernization, especially the leaders who have promoted it, avoid discussing at meetings the possibility of building the dam. This would intensify conflicts 
among irrigators, and they fear that many will drop out or withdraw from the modernization. For the time being, what they have agreed is that, if they join the fight against the dam, they will do so individually, but not on behalf of the irrigators' community, because they fear that the Andalusian Council will again retaliate against them, especially affecting all those families who are investing their own money to defend their water rights.

Clearly, the move toward modernizing irrigation is generating divisions within the community of farmers and debilitating the unified front to protect the Río Grande; especially breaking up collective, community water management. As drip irrigation expands, the threat is no longer only external, but also internal; now everyone is attempting to access underground water, but without any actual control over available water. This is how one of the Coordinating Body leaders expressed this: "This is a threat that is not so easy to see, and everyone who has water next to their field is filching from the river. The problem is that this is no longer a threat against us all ... when each is consuming water uncontrolledly, then we are the threat" (interview, local leader of JARA, 20 June 2016).

The Coordinating Body is aware that the dam project was discarded from the official policies and plans. However, the fight is not over yet. A local leader describes the situation: "There is nothing official, but the threat is there. We have won some battles, but we have not won the war yet" (interview, 4 May 2017).

\section{Conclusions}

This article has analyzed how Spain's late 19th-century hydraulic-utopian modernity project, increasingly dominated by positivist scientific-technological knowledge, has deeply colored the last century's efforts to tame and unify rivers, territories, and people, configuring new power relationships that would cram vernacular political-normative and agro-cultural diversities into a single hydraulic-administrative mega system that aligns norms, resources, practices, discourses, and human behaviors. Illustrative is the case of the Guadalhorce Valley, where regenerationist hydro-territorial utopia and disciplinary Franquist dystopia neatly entwine, breaking down traditional irrigation management practices to integrate them into a single, totalizing project. New hydrosocial connections transferred water from the Guadalhorce Valley to Málaga city, weakening and rearranging rural livelihoods, drowning headwater communities and containing populations in colonization towns. Hydraulic modernity for the Guadalhorce basin has expanded at the expense of local, vernacular realities, feeding uncontrolled tourism, and urban growth in Málaga. Consequently, water demand pressures intensify, provoking shortages, paradoxically giving rise to building new modernist water projects.

After the political regime change, in response to this crisis, alternative bodies of knowledge have emerged and/or been revitalized, now joining together to reject technocratic management of rivers, which — far from resolving the water management crisis—-worsen it by monopolizing resources, truth claims and power. When construction of the Río Grande dam in the Guadalhorce's sub-basin was announced in 2001, social contestations emerged, especially from smallholder and elder residents, expressing their rootedness in their fields and traditional irrigation practices, and mobilizing vernacular knowledge and customary organizational norms and forms. They built strength by joining other mobilizations, and were supported by networks of scholars and intellectuals from different universities in Spain. Their counter-studies showed how scientific knowledge may be mobilized, both to defend powerful sectors' interests and to co-develop, hybridize and grow stronger with rural experiences and the knowledge of anti-dam movements. This way, contestations to dominant knowledge can position new stakeholders to defend their livelihoods and construct socio-environmentally fairer alternatives.

Along with the protagonism by rural people, the article has shown the key importance of associating through multi-stakeholder, multi-scalar networks. The Jara Association joined in the struggle, supporting defense of the Río Grande, making ecological knowledge of the river more visible and highlighting the importance of keeping the river alive and free of dams. Their mobilization connected heterogeneous stakeholders, facilitating extension toward diverse scales and strategically 
integrating diverse forms of knowledge: Grassroots and scientific know-how. Strategically studying and questioning the technical-scientific knowledge supporting dam construction has materialized their contestations in legal allegations, which-along with communicational strategies and trans-local cooperation with other social networks-managed to stop dam construction. In this way, we have shown how the dynamic knowledge contestations, embedded in changing institutional-political, socio-economic and techno-material networks and coalitions, have constantly reconfigured the hydrosocial territory of Río Grande valley.

We have demonstrated how the movement has had (and continues having) a catalytic effect to unite multiple stakeholders and bodies of knowledge, connected on different scales, when the threat is external and visible (i.e., the mega hydraulic project that extracts water for the benefit of external urban centers elsewhere). However, this becomes more complex when this endeavor is subtly disguised as an internal community project, 'bottom-up' and 'participatory' (technical-modernistic development of irrigators' communities for the 'common benefit'). Paradoxically, the ideology underpinning the social struggle in Río Grande-protecting the river, alive and free-became the strategy that official entities and environmentalist groups used to restrict and alter key societal sectors' and irrigators communities' water rights to the Río Grande. Contestations against this phenomenon divide the community and complicate the unified battle against transferring rural water to the city. Some farmers internalize the utopian discourses presented by proposals to modernize irrigation and transform their traditional practices, unconsciously or consciously, to maintain their linkages with the land. Other farmers resist modernization, using their customary rights in order not to lose local, collective water self-management.

In this context, from a political ecology approach, this article has reflected on the challenges that societal movements as in Río Grande's struggle face. Beyond opposing dam construction to defend the river, we argue that their challenges and efforts must center on standing up for water usage rights and collective water management, and thereby generate collective co-construction of knowledge, norms and practices to defend the river. Strategic, critical-conscious, publicly discussed integration of multiple types of knowledge, multiple stakeholders, and multiple scales fosters the autonomous construction of a deep-rooted hydrosocial territory, to ensure the survival and permanence of their legacy at the same time as ongoing renewal of their cultural practices.

Defending the Río Grande and its whole environment from the construction of any large hydraulic project transferring its water means getting free of that hydraulic utopia that drowned towns and channeled the Guadalhorce River. The fight for the Río Grande poses the challenge of rethinking water management in terms of less universalistic and homogenizing concepts, to yield more diversified collective water management, where economic sectors' performance matches their territorial capacities and does not compromise other rural zones' social well-being.

Author Contributions: For this article, B.D.A. (PhD research) and L.d.P. (MSc research) did literature research, research preparation, and fieldwork investigation; B.D.A., R.B. and L.d.P. have organized, conceptualized and written the article.

Funding: This research received no external funding. Bibiana Duarte-Abadía has a Colciencias $\mathrm{PhD}$ research fellowship.

Conflicts of Interest: The authors declare no conflict of interest.

\section{References}

1. Ortí, A. Política hidráulica y cuestión social: Orígenes, etapas y significados del regeneracionismo hidráulico de Joaquín Costa. Agr. y Soc. 1984, 32, 11-107.

2. Boelens, R.; Post Uiterweer, N.C. Hydraulic Heroes: The Ironies of Utopian Hydraulism and its Politics of Autonomy in the Guadalhorce Valley, Spain. J. Hist. Geogr. 2013, 44, 44-58. [CrossRef]

3. Duarte-Abadía, B.; Boelens, R. Colonizing Rural Waters: The Politics of Hydro-Territorial Transformation in the Guadalhorce Valley. Water Int. 2019. [CrossRef]

4. Swyngedouw, E. Technonatural revolutions: The scalar politics of Franco's hydrosocial dream for Spain, 1939-1975. Trans. Inst. Br. Geogr. 2007, 32, 9-28. [CrossRef] 
5. Jiménez Sánchez, M.; Poma, A. Lógicas en conflicto. Conocimiento experto y política en la movilización social en defensa de río Grande (Málaga). Arxius de Sociología 2011, 25, 59-70.

6. Poma, A.; Gravante, T. Analyzing Resistance from below: A Proposal of Analysis Based on Three Struggles against Dams in Spain and Mexico. Cap. Nat. Soc. 2015, 26, 59-76. [CrossRef]

7. Du Pré, L. Río Grande's Troubled Water: The Struggles between Rural water Users and External Actor Alliances over the Materialization of the Rural Hydrosocial Territory. Master's Thesis, Wageningen University, Wageningen, The Netherlands, August 2017.

8. Long, N. Development Sociology: Actor Perspectives; Routledge: London, UK, 2001; pp. 9-92.

9. Boelens, R.; Hoogesteger, J.; Swyngedouw, E.; Vos, J.; Wester, P. Hydrosocial Territories: A Political Ecology Perspective. Water Int. 2016, 41, 1-14. [CrossRef]

10. Zikos, D.; Thiel, A. Action research's potential to foster institutional change for urban water management. Water 2013, 5, 356-378. [CrossRef]

11. Boelens, R. Water, Power and Identity. The Cultural Politics of Water in the Andes, 1st ed.; Routledge: London, UK; New York, NY, USA, 2015; p. 359. ISBN 978-0-415-71918-6.

12. Duarte-Abadía, B.; Boelens, R.; Roa-Avendaño, T. Hydropower, encroachment and the repatterning of hydrosocial territory: The case of Hidrosogamoso in Colombia. Hum. Organ. 2015, 74, 243-254. [CrossRef]

13. Hommes, L.; Boelens, R.; Maat, H. Contested hydro-social territories and disputed water governance: Struggles and competing claims over the Ilisu Dam development in southeastern Turkey. Geoforum 2016, 1, 9-20. [CrossRef]

14. Swyngedouw, E.; Boelens, R. And not a single injustice remains-Hydro-territorial colonization and techno-political transformation in Spain. In Water Justice; Boelens, R., Perreault, T., Vos, J., Eds.; Cambridge University Press: Cambridge, MA, USA, 2018; pp. 115-134.

15. Zinzani, A. Development initiatives and transboundary water politics in the Talas waterscape (Kyrgyzstan-Kazakhstan): Towards the Conflicting Borderlands Hydrosocial Cycle. In Water, Technology and the Nation-State; Menga, F., Swyngedouw, S., Eds.; Routledge: London, UK, 2018; pp. 147-166.

16. Marks, D. Assembling the 2011 Thailand floods: Protecting farmers and inundating high-value industrial estates in a fragmented hydro-social territory. Political Geogr. 2019, 68, 66-76. [CrossRef]

17. Hoogesteger, J.; Boelens, R.; Baud, M. Territorial pluralism: Water users' multi-scalar struggles against state ordering in Ecuador's highlands. Water Int. 2016, 41, 91-106. [CrossRef]

18. French, A. Webs and Flows: Socionatural Networks and the Matter of Nature at Peru's Lake Parón. Ann. Am. Ass. Geogr. 2019, 109, 142-160. [CrossRef]

19. Baletti, B. Ordenamento Territorial: Neo-developmentalism and the struggle for territory in the lower Brazilian Amazon. J. Peasant Stud. 2012, 39, 573-598. [CrossRef]

20. Linton, J.; Budds, J. The hydro-social cycle: Defining and mobilizing a relational-dialectical approach to water. Geoforum 2014, 57, 170-180. [CrossRef]

21. Rodríguez-de-Francisco, J.C.; Boelens, R. PES hydrosocial territories: De-territorialization and re-patterning of water control arenas in the Andean highlands. Water Int. 2016, 41, 140-156. [CrossRef]

22. Del Bene, D.; Scheidel, A.; Temper, L. More dams, more violence? A global analysis on resistances and repression around conflictive dams through co-produced knowledge. Sustain. Sci. 2018. [CrossRef]

23. Bebbington, A.; Bebbington, D.H.; Bury, J. Federating and defending: Water, territory and extraction in the Andes. In Out of the Mainstream: Water Rights, Politics and Identity; Boelens, R., Getches, D., Guevara-Gill, A., Eds.; Earthscan: London, UK; Washington, DC, USA, 2010; pp. 307-327.

24. Boelens, R. Water Rights Arenas in the Andes. Upscaling the Defense Networks to Localize Water Control. Water Altern. 2008, 1, 48-65.

25. Hoogesteger, J.; Verzijl, A. Grassroots scalar politics: Insights from peasant water struggles in the Ecuadorian and Peruvian Andes. Geoforum 2015, 62, 13-23. [CrossRef]

26. Meehan, K. Disciplining de facto development: Water theft and hydrosocial order in Tijuana. Environ. Plan. D Soc. Space 2013, 31, 319-336. [CrossRef]

27. Swyngedouw, E. The political economy and political ecology of the hydrosocial cycle. J. Contemp. Water Res. Educ. 2009, 142, 56-60. [CrossRef]

28. Hommes, L.; Boelens, R. Urbanizing rural waters: Rural-urban water transfers and the reconfiguration of hydrosocial territories in Lima. Political Geogr. 2017, 57, 71-80. [CrossRef] 
29. Swyngedouw, E. Liquid Power: Contested Hydro-Modernities in 20th Century Spain; MIT Press: Cambridge, MA, USA, 2015; p. 320.

30. Recercat. Historia, Política y Ciencia: El Papel de los Expertos en el Debate Sobre el Agua en España. Available online: http:/ / www.recercat.net/bitstream/2072/4783/1/Recerca+historia+aigua+Espanya.pdf (accessed on 14 September 2015).

31. Kaika, M. Dams as symbols of modernization: The urbanization of nature between geographical imagination and materiality. Ann. Assoc. Am. Geogr. 2006, 96, 276-301. [CrossRef]

32. Illich, I. $\mathrm{H}_{2} \mathrm{O}$ and the Waters of Forgetfulness; University of California: Marion Boyars, CA, USA, $1985 ;$ p. 92.

33. Kaika, M. Cities of flows. In Modernity, Nature and the City; Routledge: London, UK, 2005; p. 200.

34. Heynen, N.; Swyngedouw, E. Urban political ecology, justice and the politics of scale. Antipode 2003, 34, 898-918.

35. Nixon, R. Unimagined communities: Developmental refugees, megadams and monumental modernity. New Form. 2010, 69, 62-80. [CrossRef]

36. Boelens, R.; Shah, E.; Bruins, B. Contested Knowledges: Large Dams and Mega-Hydraulic Development. Water 2019, 11, 416. [CrossRef]

37. Hoogendam, P.; Boelens, R. Dams and Damages. Conflicting epistemological frameworks and interests concerning "compensation" for the Misicuni project's socio-environmental impacts in Cochabamba, Bolivia. Water 2019, 11, 408. [CrossRef]

38. Hoffmann, C. From small streams to pipe dreams-The hydro-engineering of the Cyprus conflict. Mediterr. Politics 2018, 23, 265-285. [CrossRef]

39. Zikos, D.; Sorman, A.H.; Lau, M. Beyond water security: Asecuritisation and identity in Cyprus. Int. Environ. Agreem. Politics Law Econom. 2015, 15, 309-326. [CrossRef]

40. Hidalgo-Bastidas, J.P.; Boelens, R.; Isch, E. Hydroterritorial Configuration and Confrontation: The Daule-Peripa Multipurpose Hydraulic Scheme in Coastal Ecuador. Latin Am. Res. Rev. 2018, 53, 517-534. [CrossRef]

41. Fox, C.; Sneddon, C. Political Borders, Epistemological Boundaries, and Contested Knowledges: Constructing Dams and Narratives in the Mekong River Basin. Water 2019, 11, 413. [CrossRef]

42. Espeland, W.N.; Stevens, M.L. Commensuration as a social process. Annu. Rev. Sociol. 1998, 24, $313-343$. [CrossRef]

43. Bacon, F. The New Atlantis; Kessinger Publishing Co: Montana, MT, USA, 2009; Published in 1626 and 1627.

44. Bentham, J. The Principles of Morals and Legislation; Prometheus Books: Amherst, NY, USA, 1988. First published in 1781 .

45. Bentham, J. Panopticon; or the Inspection-house. In The Panopticon Writings; Bozovic, M., Ed.; Verso: London, UK, 1995; pp. 29-95, Published in 1787-1791.

46. Achterhuis, H. De erfenis van de utopie [Utopia's Heritage]; Ambo: Amsterdam, The Netherlands, 1998 ; p. 444.

47. Boelens, R. Rivers of Scarcity. Utopian water Regimes and Flows Against the Current; Wageningen University: Wageningen, The Netherlands, 2017.

48. Costa, J. Política hidráulica: Misión social de los riegos en España; Biblioteca J. Costa: Madrid, Spain, 1911; p. 353.

49. Estevan, A.E. Herencias y Problemas de la Politica Hidráulica Española; Bakeaz: Bilbao, España, 2008 ; p. 163. ISBN 978-84-88949-95-0.

50. Fernández Clemente, E. De la Utopía de Joaquín Costa a la Intervención del Estado: Un Siglo de Obras Hidráulicas en España; Universidad de Zaragoza: Zaragoza, Spain, 2000; p. 65. ISBN 84-930255-6-9.

51. Menga, F.; Swyngedouw, S. Water, Technology and the Nation-State; Routledge: London, UK, 2018.

52. Gajic, T. Fronteras líquidas: Agua y bio-política de la territorialidad en España. Arizona J. Hispan. Cultur. Stud. 2007, 11, 25-41. [CrossRef]

53. Swyngedouw, E. Modernity and Hybridity: Nature, Regeneracionismo, and the Production of the Spanish Waterscape, 1890-1930. Ann. Assoc. Am. Geogr. 1999, 89, 443-465. [CrossRef]

54. Bauman, Z. Liquid Times. Living in an Age of Uncertainty; Polity Press: Cambridge, UK, 2007 ; p. 111. ISBN 978-07456-3986-4.

55. Valladares, C.; Boelens, R. Extractivism and the rights of nature: Governmentality,"convenient communities" and epistemic pacts in Ecuador. Environ. Politics 2017, 26, 1015-1034. [CrossRef]

56. Smith, N. Uneven Development: Nature, Capital and the Production of the SPACE; Blackwell: Oxford, UK, 1984; Volume 3. 
57. Bromley, D.W. The 2016 Veblen-Commons Award Recipient: Daniel W. Bromley: Institutional Economics. J. Econom. Issues 2016, 50, 309-325.

58. Ibele, B.; Sandri, S.; Zikos, D. Endogenous versus exogenous rules in water management: An experimental cross-country comparison. Mediter. Politics 2017, 22, 504-536. [CrossRef]

59. McCully, P. Silenced Rivers. In The Ecology and Politics of Large Dams; Zed books: London, UK; New York, NY, USA, 2001; p. 359.

60. Boelens, R. Cultural Politics and the Hydrosocial Cycle: Water, Power and Identity in the Andean Highlands. Geoforum 2014, 57, 234-247. [CrossRef]

61. Achterhuis, H.; Boelens, R.; Zwarteveen, M. Water property relations and modern policy regimes: Neoliberal utopia and the disempowerment of collective action. In Out of the Mainstream: Water Rights, Politics and Identity; Boelens, R., Getches, D., Guevara, A., Eds.; Earthscan: London, UK, 2010; pp. 27-56. ISBN 184971455X.

62. Boelens, R.; Vos, J. The danger of naturalizing water policy concepts. Water productivity and efficiency discourses from field irrigation to virtual water trade. J. Agric. Water Manag. 2012, 108, 16-26. [CrossRef]

63. Espeland, W. The struggle for water. In Politics, Rationality, and identity in the American Southwest; University of Chicago Press: Chicago, IN, USA; London, UK, 1998; p. 281. ISBN 9780226217932.

64. Vos, J.; Boelens, R. Sustainability Standards and the Water Question. Dev. Chang. 2014, 45, 205-230. [CrossRef]

65. Illich, I. Vernacular values. Philosiphica 1980, 26, 2-32.

66. Stuiver, M.; Leeuwis, C.; van der Ploeg, J.D. The power of experience: farmers' knowledge and sustainable innovations in agriculture. In Seeds of Transitions; Wiskerke, H., van der Ploeg, J.D., Eds.; Royal Van Gorcum: Assen, The Netherlands, 2004; pp. 93-118.

67. Arce, A.; Long, N. The dynamics of knowledge interfaces between Mexican agricultural bureaucrats and peasants: A case study from Jalisco. Boletín de Estudios Latinoamericanos y del Caribe 1987, 43, 5-30.

68. Foucault, M. Power/knowledge. Selected interviews and other writings 1972-1978. In Power/Knowledge: Selected Interviews and Other Writings 1972-1978; Gordon, C., Ed.; Pantheon Books: New York, NY, USA, 1980; p. 282.

69. Bebbington, A. Movements, modernizations, and markets. In Liberation Ecologies: Environment, Development, Social Movements, 1st ed.; Peet, R., Watts, M., Eds.; Routledge: London, UK; New York, NY, USA, 1996; pp. 86-109. ISBN 0-203-03292-6.

70. Pfaffenberger, B. Technological dramas. Sci. Technol. Hum. Values 1992, 17, 282-312. [CrossRef]

71. Sanchis-Ibor, C.; Boelens, R.; García-Mollá, M. Collective irrigation reloaded. Re-collection and re-moralization of water management after privatization in Spain. Geoforum 2017, 87, 38-47. [CrossRef]

72. Winner, L. Upon opening the black box and finding it empty: Social constructivism and the philosophy of technology. Sci. Technol. Hum. Values 1993, 18, 362-378. [CrossRef]

73. Maurice, J.; Serrano, C. J. Costa: Crisis de la Restauración y Populismo (1875-1911); Siglo XXI Editores: Madrid, Spain, 1977; p. 245. ISBN 978-84-323-0258-9.

74. Pacheco, C. Patterns Changes of Land Use/Cover over Time in Rio Grande, River Watershed-Spain: Intensification of the Irrigated Agriculture; Research Project; Institute for Biodiversity and Ecosystem Dynamics and CEDLA, University of Amsterdam: Amsterdam, The Netherlands, August 2017.

75. Gómez Moreno, M.L. El Genal apresado: ¿agua y planificación: Desarrollo sostenible o crecimiento ilimitado? 1st ed.; Bakeaz: Bilbao, Spain, 1998; p. 288. ISBN 9788488949332.

76. Puche, F. Río Grande: Cuaderno de Trabajo por la Nueva Cultura del Agua; Mesa de Amig@s de los Ríos: Málaga, Spain, 2003; ISBN 84-930029-4-1.

77. Gorostiza, S.; March, H.; Saurí, D. Piercing the Pyrenees, Connecting Catalonia to Europe: The ascendancy and dismissal of the Rhône Water Transfer Project (1994-2016). In Water, Technology and the Nation-State; Menga, F., Swyngedouw, S., Eds.; Routledge: London, UK, 2018; pp. 34-48.

78. Gobierno de España, Ministerio Para La Transición Ecológica. Available online: http://www.mapama. gob.es/es/biodiversidad/temas / espacios-protegidos/red-natura-2000/rn_pres_tipos_lugares_LIC.aspx (accessed on 20 January 2019). 
79. Sampedro, D.; y Del Moral, L. Tres décadas de política de aguas. Cuadernos Geográficos 2014, 53, 36-67. Available online: http:/ / hdl.handle.net/11441/43624 (accessed on 15 January 2017).

80. Genovés, J.C.; García Moyà, M.; Sanchis Ibor, C.; Vega Carrero, V.; Avellà Reus, L. Case Studies Synthesis, Spain-Institutional Framework for Local Irrigation Management in Spain: The Case of Upper Genil and Low Jucar Valleys. Available online: http:/ / www.isiimm.agropolis.org/OSIRIS/report/Isiimm-SynthesisSpain_ eng.pdf (accessed on 22 October 2018). 